British Journal of Marketing Studies

Vol. 8, Issue 4, Pp.49-66, July, 2020

Published by ECRTD- UK

Print ISSN: 2053-4043(Print), Online ISSN: 2053-4051(Online)

\title{
A STUDY OF BRANDING STRATEGY INFLUENCING BRAND EQUITY FOR YOUTH IN THE PAKISTAN'S DOMESTIC NEW LUXURY APPAREL INDUSTRY
}

\author{
Dr. Junaid Khan, Dr. Umair Zahid, Dr. Rizwan Tariq, Dr. Nosheen Maqbool, Dr. Mudasir \\ Hussain
}

University of the West of Scotland, London, United Kingdom

\begin{abstract}
This paper aims to explore the key branding strategies influencing the young customers of Pakistan to buy a new domestic new luxury apparel brand and results in strong brand equity. Further, the current study also provides an in depth understanding between the old and new luxury branding. This study has employed quantitative research analysis with the help of a deductive approach. For collecting quantitative data, Likert Scale Based questionnaire were distributed among 125 young customers who had experience of buying domestic new luxury apparel brand in Pakistan. The results of this study depict that branding strategies like store image, brand elements, influencers and web advertising have positive effects on brand equity as it influences young consumer to buy a domestic new luxury apparel in Pakistan. The study is limited to young consumers of Karachi, Pakistan. Marketers have adopted different strategies for attracting the customers towards their products and to develop strong brand equity. With the emergence of new luxury, brands are experimenting various strategies to attract young consumers. In Pakistan, few studies have investigated traditional luxury however, no studies were conducted in terms of new luxury. This study has revealed four branding strategies influencing young consumers in Pakistan to buy a domestic new luxury apparel and also building strong brand equity for apparel brands.
\end{abstract}

KEYWORDS: luxury, new luxury, branding, brand equity, influencers, brand elements, web advertising, store image, apparel, youth.

\section{INTRODUCTION}

\section{Background of research}

The industry of luxury apparel has gained significant consideration over the course of past 20 years (Fionda and Moor, 2009; Kapferer and Bastien, 2009; Tynan, McKechnie and Chhoun, 2010). In the domain of academics, due to the introduction of luxury conglomerates such as Gucci and LVMH (Louis Vuitton - Moet Hennessey), extensive research has been done by various researchers that enabled improvements and facilitated the growth of this sector. Following are some of the characteristics that define a luxury brand or item; high-quality brand awareness, status of the symbol, premium pricing and exclusivity (Bruce and Kratz, 2007; Truong et al., 2008; Atwal and Williams, 2009; Fionda and Moore, 2009; Kapferer and Bastien, 2009; Okonkwo, 2009; Tynan et al., 2010). The features of different luxury brands have been furthered narrowed by Heine (2012) in the below table: 
British Journal of Marketing Studies

Vol. 8, Issue 4, Pp.49-66, July, 2020

Published by ECRTD- $\boldsymbol{U K}$

Print ISSN: 2053-4043(Print), Online ISSN: 2053-4051(Online)

\begin{tabular}{|c|c|c|c|}
\hline $\begin{array}{c}\text { Main } \\
\text { Features }\end{array}$ & Supplier Features & $\begin{array}{l}\text { Tangible } \\
\text { Features }\end{array}$ & $\begin{array}{c}\text { Intangible } \\
\text { Features }\end{array}$ \\
\hline Price & & Price & \\
\hline \multirow{6}{*}{ Quality } & $\begin{array}{l}\text { Supplier's } \\
\text { expertise }\end{array}$ & Material & \\
\hline & $\begin{array}{l}\text { Difficulty of } \\
\text { production }\end{array}$ & $\begin{array}{l}\text { Principles of } \\
\text { Production }\end{array}$ & \\
\hline & & Labour & \\
\hline & & Product Features & \\
\hline & & Product Size & \\
\hline & & Services & \\
\hline Aesthetics & & & Aesthetics \\
\hline Rarity & & Rarity & \\
\hline Uniqueness & & & Uniqueness \\
\hline Symbolism & & & Symbolism \\
\hline
\end{tabular}

Table 1: Features of Luxury Products. Source: (Heine, 2012)

Truong et al. (2008) and Tynan et al. (2010) have further characterised luxury brands into traditional luxury brands and new luxury brands. As an example, Channel, Louis Vuitton and Gucci can be categorised as traditional luxury brands. On the other hand, there are few features of new luxury brands that make it diverse from traditional luxury brands. Consequently, the target market of traditional luxury goods is different from new luxury goods because they are professed as the symbol of prestige and quality and only a few numbers of consumers are targeted. Silverstein and Fiske (2005) stated that new luxury goods are more accessible than old luxury goods, but more limited than conventional mass-market goods, new luxury goods have elements of craftsmanship, but are not completely hand-made or assembled manually. While old luxury is about exclusivity, the goods are priced to ensure that only the top earning 1-2 per cent of consumers can afford them and they carry a sense of elitism.

According to Truong, McColl and Kitchen (2009) the new luxury brands target the younger generation as they are financially flexible and inconsistent in choosing the brands. Thus, new luxury brands compete in the highly intense market and are perceived as prestigious. However, their pricing is slightly higher than the middle range pricing. The examples of new luxury brands include Ralph Lauren and Calvin Klein (Truong et al., 2008).

As highlighted by Fionda and Moore (2009), luxury can be found under different categories, however, one the biggest share of luxury belongs to the fashion industry. Hence, this study focuses on the domestic new luxury fashion industry of Pakistan. Tynan et al. (2010) elucidate that the demand of luxury products is increasing in a consistent manner and this is more demanded by the emerging markets like China, Russia, Pakistan, India, and the Middle East as citizens of these countries have increased desire for luxury products (Shukla and Purani, 2012, MSCI Index, 2019). The growing population and the increasing demand in these emerging markets, including Pakistan has instigated a trend of spending more on the luxury products. Thus, the concept of 'luxury' has changed to "new luxury' which is "fashionable" and "affordable" (Silverstein and Fiske 2005; Li and Su, 2007). 
British Journal of Marketing Studies

Vol. 8, Issue 4, Pp.49-66, July, 2020

Published by ECRTD- UK

Print ISSN: 2053-4043(Print), Online ISSN: 2053-4051(Online)

Kim and Ko (2012) stated that the luxury industry has been witnessing growth and is among the most lucrative and appealing businesses of the world. The luxury brands bring the best fashion in the market as they are regarded as the market leaders that drive various imitators for the mass market. The world of modern fashion is highly occupied by the luxury fashion therefore luxury fashion branding has become a crucial topic for the researchers (Emond, 2009; Ko and Megehee, 2012).

In this context, the concept of brand equity serves as a competitive tool as building strong brand equity brings success for the brands. This becomes more evident as competition is becoming intense between brands, as several choices are available for consumers (Kotler \& Keller, 2012). Strong brand equity results in greater loyalty, less vulnerability to competitors' marketing actions, and greater opportunities to expand (Leone et al., 2006). According to Keller (1993); Lehmann, Keller, and Farley (2008); Jung and Shen, (2011); Selvakumar and Vikkraman, (2011); Mutsikiwa et al. (2013); Alnsour and Subbah, (2018), brand equity is the added value that the brand name gives to a product.

Organisations devise a combination of different strategies in order to deliver superior value to customers and to influence their purchasing pattern. (Ghodeswar, 2008; Farhana, 2012; Hanaysha et al., 2013; Tsimonis and Dimitriadis, 2014; Sasmita and Mohd Suki, 2015; Alnsour and Subbah, 2018). In this scenario, branding strategies are often considered as the most significant means of building brand equity (Keller, 2010; Bruhn, Schoenmueller and Schafer, 2012; Emari, Jafari and Mogaddam, 2012; Farhana, 2012; Aaker and Biel, 2013).

According to the MSC index, (2018), Pakistan is in line with the top emerging markets which have boosted the market with investors, especially the apparel industry of Pakistan which has significantly contributed towards the betterment of the economy (Rahman et al., 2014). Moreover, it has been analysed that the urban areas have welcomed the presence of brands in their localities due to the increasing fashion trends in the globalised world. The affordability of luxury brands has transitioned more towards the inclusion of broader market rather than high class only (McColl and Kitchen, 2009). The traditional luxury brands were focused to market their products to the upper-class individuals. However, it limited their market share and the concept of new luxury has emerged. The concept of new luxury has been adopted by the domestic luxury apparel brands in Pakistan to provide alternative affordable and fashionable luxury as compared to the traditional luxury (Iris Communications, 2017).

New luxury has expanded the number of consumers in the market which has accelerated the competition between the luxury apparel brands. In Pakistan, the fashion apparel industry has been achieving steady growth and the major force behind such growth is youth, which accounts for about $63 \%$ of the overall Pakistani population (Pakistan and Gulf Economist, 2018). Therefore, the demand for domestic new luxury apparel brands has significantly increased as youth spend more money on luxury apparel (Jung and Shen, 2011; Kundi, 2018; Pakistan and Gulf Economist, 2018). To compete with traditional luxury brands, domestic new luxury apparel brands have started designing their branding strategies to drive customers' attention towards their brand (Iris Communications, 2017). Thus, this study aims to identify effective branding strategies of domestic new luxury apparel brands in Pakistan that influence young consumers to purchase their products. 
British Journal of Marketing Studies

Vol. 8, Issue 4, Pp.49-66, July, 2020

Published by ECRTD- UK

Print ISSN: 2053-4043(Print), Online ISSN: 2053-4051(Online)

\section{LITERATURE REVIEW}

\section{Concept of Luxury and New Luxury}

The literature regarding the field of marketing is extensive and has been evaluated worldwide. Godey et al. (2012) describe that the concept of luxury is ambiguous, and many research studies have defined as per their understanding. Hence, the term luxury does not have a specific definition that can be used worldwide. According to Oxford Dictionary (2014) luxury is defined as "an essential, desirable item which is expensive or difficult to obtain", Kapferer (1997, p253) "Luxury defines beauty; it is an art applied to functional items. They offer more than mere objects: they provide reference of good taste... Luxury is the appendage of the ruling classes."

Overall, the concept of luxury pertains to obtaining something precious in order to enhance the social status of individuals and according to the study of Okonkwo (2009), the author has explained luxury from the perspective of sociopsychology due to the connection it has on the culture and lifestyle of individuals. In the past, it was noted that only the elite people living in a country have access to luxury products, however, today, the luxury industry has changed in a drastic manner (Vigneron and Johnson, 2004). Hence, the concept of 'new luxury' was introduced to the world, when the consumer attitude changed due to cognitive development. Michael Silverstein and Neil Fiske, researchers of the Boston Consulting Company, were the first who presented the concept of "new luxury" in their book "Trading Up" (Silverstein et al., 2005).The following table describes new luxury and old luxury from the research of Silverstein, Butman and Fiske (2005):

\begin{tabular}{|l|l|l|}
\hline & New Luxury & Old Luxury \\
\hline Affect & Engaging & Aloof \\
\hline Availability & Affordable & Exclusive \\
\hline Price & Premium & Expensive \\
\hline Quality & Mass Artisanal & Handmade \\
\hline Social Basis & Value Driven & Elitist \\
\hline
\end{tabular}

Table 2: Description and categorisation of luxury; Source: Adapted from Silverstein, Butman and Fiske (2005).

\section{Pakistani Luxury Customer}

Bashir et al. (2013) describe that consumers who purchase luxury products in Pakistan are different from those of developed countries considering the differences in their cultural values and age. Additionally, according to a report published by Pakistan and Gulf Economist (2018), one of the main groups of luxury brand consumer are the young people of Pakistan and is rapidly growing the country and totals to $63 \%$ of the total population (World Population Review, 2018). It has also been noted that Pakistan is making impressive growth in the luxury sector due to huge amounts of spending by much of its younger population and an increase in the number of socialising trends and affluence (Bain and Company, 2016). Furthermore, Pakistan is becoming one of the fastest-growing retail market of the world because of the increasing number of youth and the carefree attitude they have adopted during the process of 
shopping. As such, the disposable income of Pakistan has increased two-fold since 2010, and is expected to continuously rise by $8.2 \%$ from 2016 to 2021 , according to the study published by Euro monitor International (Samaa, 2017):

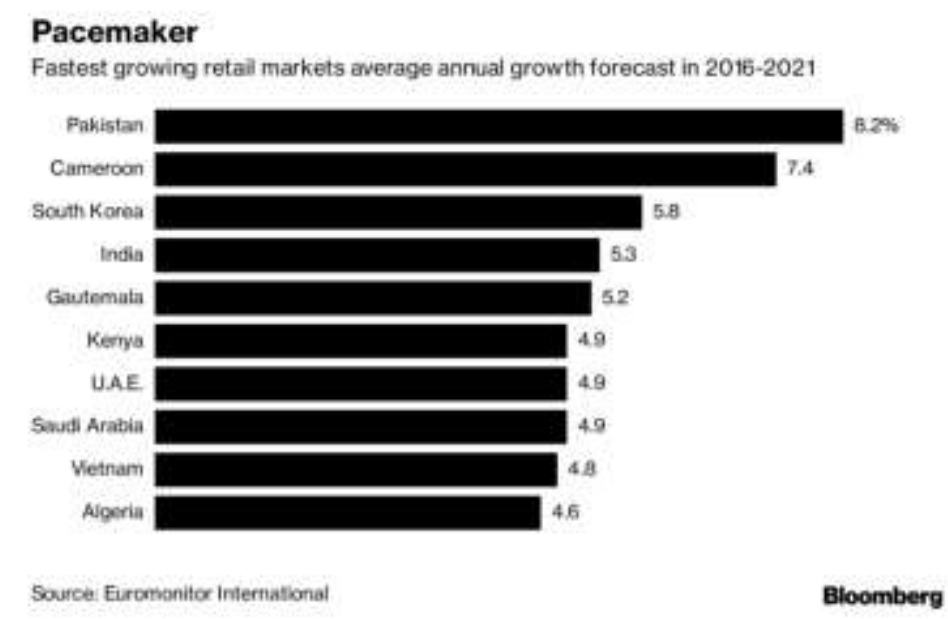

Figure 1: Growing retail markets. Source: (Samaa, 2017)

\section{Branding strategies}

The emergence of 'new luxury' has gained significant attention (Fionda and Moore, 2009; Kapferer and Bastien, 2009; Tynan et al., 2010). Silverstein et al. (2005); Truong, McColl, \& Kitchen, (2009) stated that 'many organisations are now moving away from the traditional methods of attracting consumers and are willing to experiment with new methods to tap into the potential market'. Organisations have adopted a combination of different branding strategies in developing strong brand equity, which has influenced the purchasing pattern of customers (Farhana, 2012). Following are the strategies discovered in this study.

\section{Store Image}

Store image pertains to the perceptions the customers have in their minds regarding the positioning of the store (Lindquist, 1974; Martineau, 1958). The characteristics of store image are as follows, "physical environment, services levels, and merchandise quality" (Zimmer and Golden, 1988)

\section{Brand Element}

Keller (2008) describes brand elements as visual or verbal information whose purpose is to identify and differentiate between different products. Some of the most common brand elements are "names, logos, symbols, characters, packaging and slogans"

\section{Influencers}

Influencer marketing pertains to the promotion and selling of products by hiring popular people who usually have a high fanbase on social media platforms and is becoming one of the essential parts of social media marketing (Morrison, 2015). Influencer marketing differs from celebrity marketing because all individuals who possess a large number of followers on different social media platform is eligible to become an influencer for the brand or product. 
According to Schlosser, Shavitt and Kanfer (1999) information that is available or provided through 'web advertising' is professed as trustworthy due to the feature of interactivity and gaining providing immediate access to information regarding the product or service.

\section{Brand Equity}

Hoeffler and Keller (2002) explain that brand equity relates to a value-added activity which improves the overall worth of the brand for organisation and consumers. Furthermore, Aaker (1991) stated that brand equity is classified into four categories: brand loyalty, brand awareness, perceived quality and brand association. According to Keller 1993; Lehmann, Keller, and Farley 2008; Jung and Shen, 2011; Selvakumar and Vikkraman, 2011; Mutsikiwa et al., 2013; Alnsour and Subbah, 2018) building strong brand equity has become a priority for all the organisations as it drives value for the brand. In this scenario, branding strategies plays a vital role in building strong brand equity for brands, especially luxury brands.

\section{Conceptual framework}

To answer the aim of this paper the researcher has developed a conceptual framework. The current study has established a below conceptual framework based on the literature.

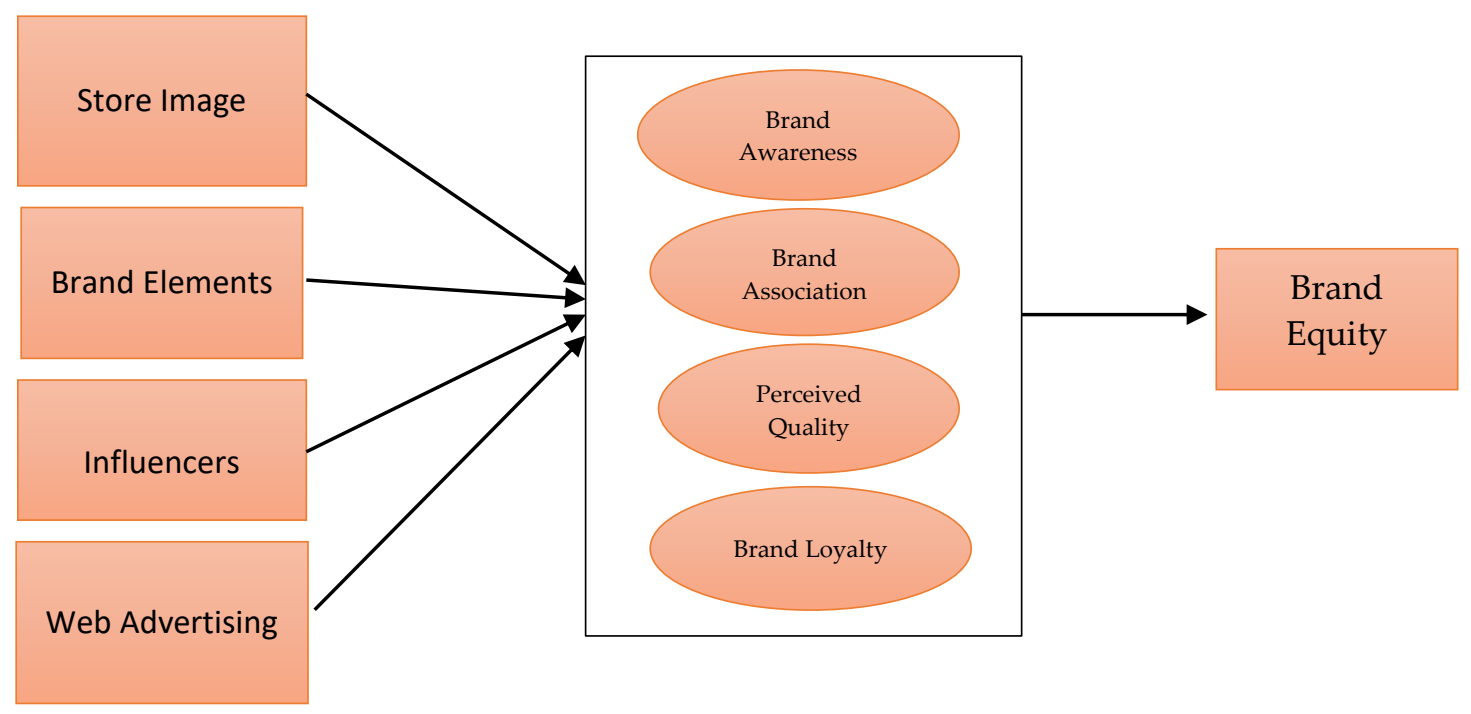

Figure 1: Conceptual Framework.

The above developed conceptual framework (Figure 1) describes the research variables. The dependent variable is Brand equity; whereas, the independent variables of the research are Store image and web advertising with the two indirect independent variables of brand elements and influencers. The connectivity between the described variables is described in the following research hypotheses.

\section{Research hypotheses}

$\mathrm{H}_{1}$ : Store image has a significant impact on the brand equity.

$\mathrm{H}_{2}$ : Web advertising has a significant impact on the brand equity.

$\mathrm{H}_{3}$ : Brand elements has a significant impact on the brand equity. 
$\mathrm{H}_{4}$ : Influencers has a significant impact on the brand equity.

\section{RESEARCH METHODOLOGY}

The research methodology plays an important part in the development of methods for determining the research results. In this study, quantitative research methodology was employed by the researcher. This methodology helps the researcher in collecting the quantitative data to reach the results of the research in an objective manner. The quantitative methodology helps the current researcher in collecting the numerical data about the perception of the young consumers about the new luxury offered by domestic new luxury apparel brands in Karachi Pakistan. The numerical data was acquired under the philosophical approach of positivism that allows the researcher to collect factual information through making real observations from the real world (Tynan, McKechnie, and Chhuon, 2010). In collecting the primary numerical data, the researcher has used five-point Likert scale to achieve the aim of this paper.

\section{Data Collection}

With the adoption of the quantitative methodology, the primary data collection technique of the survey questionnaire was applied. The questionnaire was developed on the measuring scale of Likert based on five points of strongly disagree; disagree; neutral; agree; and strongly agree. This questionnaire was distributed among the developed sample of the research for collecting a large pool of data in short period of time.

\section{Data Analysis}

For analysing the quantitative data, this study has used the SPSS software for conducting the statistical operations on the data collected through questionnaire. The arithmetical operations performed with the help of SPSS software were descriptive statistics, correlation analysis, and regression analysis. These analyses help the researcher in developing the results accordingly with the objectives in an effective manner.

\section{Sample Size and Technique}

For the distribution of the questionnaire in this study, 125 participants were selected. The participants were the young people who had an experience of buying domestic new luxury apparel brand in Karachi Pakistan. The sampling technique followed for distributing the 125 questionnaires was the non-probability convenience sampling as this allows the researcher to collect all 125 responses for completing the research in an effective manner. Moreover, the convenience sampling helps the researcher in collecting the desired responses on the convenience of the youngsters coming to shop for luxury brands.

\section{RESULTS AND DISCUSSION}

For any study, determining the results and making effective discussion on the results is considered as a significant part. The quantitative research results are discussed in terms of the statistical tests that has been applied to the collected data for checking the research hypotheses. 
British Journal of Marketing Studies

Vol. 8, Issue 4, Pp.49-66, July, 2020

Published by ECRTD- UK

Print ISSN: 2053-4043(Print), Online ISSN: 2053-4051(Online)

\section{Descriptive analysis}

The descriptive analysis or the descriptive statistics determination are the main part of the quantitative methods. The descriptive statistics analysis helps the readers in understanding the mean, skewness, and Kurtosis value of the quantitative data.

Table 3: Descriptive Statistics

\begin{tabular}{|c|c|c|c|c|c|c|c|}
\hline \multicolumn{8}{|l|}{ Descriptive Statistics } \\
\hline & $\mathbf{N}$ & Mean & & \multicolumn{2}{|c|}{ Skewness } & \multicolumn{2}{|c|}{ Kurtosis } \\
\hline & Statistic & Statistic & Statistic & $\begin{array}{l}\text { Stati } \\
\text { stic }\end{array}$ & $\begin{array}{c}\text { Std. } \\
\text { Err } \\
\text { or }\end{array}$ & $\begin{array}{l}\text { Statis } \\
\text { tic }\end{array}$ & $\begin{array}{c}\text { Std. } \\
\text { Err } \\
\text { or }\end{array}$ \\
\hline AppealingStoreImage & 125 & 4.10 & .705 & $\begin{array}{c}-.14 \\
9\end{array}$ & .217 & -.963 & .430 \\
\hline StoreImage & 125 & 4.22 & .714 & $\begin{array}{c}-.34 \\
2\end{array}$ & .217 & -.981 & .430 \\
\hline StoreImgasBrand & 125 & 4.22 & .702 & $\begin{array}{c}-.32 \\
9\end{array}$ & .217 & -.931 & .430 \\
\hline $\begin{array}{l}\text { BrandElementsSupportStr } \\
\text { ategy }\end{array}$ & 125 & 4.14 & .715 & $\begin{array}{c}-.48 \\
8\end{array}$ & .217 & -.012 & .430 \\
\hline $\begin{array}{l}\text { BrandElemntsBasedonStr } \\
\text { ategies }\end{array}$ & 125 & 4.19 & .769 & $\begin{array}{c}-.88 \\
5\end{array}$ & .217 & .776 & .430 \\
\hline $\begin{array}{l}\text { InfluencersAttractConsum } \\
\text { ers }\end{array}$ & 125 & 4.22 & .658 & $\begin{array}{c}-.44 \\
6\end{array}$ & .217 & .055 & .430 \\
\hline $\begin{array}{l}\text { ImpactofBrandInfluencers } \\
\text { OnBusiness }\end{array}$ & 125 & 4.22 & .667 & $\begin{array}{c}-.27 \\
6\end{array}$ & .217 & -.768 & .430 \\
\hline $\begin{array}{l}\text { WebAdvertisingperforme } \\
\text { d }\end{array}$ & 125 & 4.22 & .739 & $\begin{array}{c}-.38 \\
4\end{array}$ & .217 & -1.081 & .430 \\
\hline $\begin{array}{l}\text { WebAdvertisingHelpsBus } \\
\text { inessinEquity }\end{array}$ & 125 & 4.09 & .730 & $\begin{array}{l}-.13 \\
7\end{array}$ & .217 & -1.097 & .430 \\
\hline $\begin{array}{l}\text { BrandEquityincreasethelo } \\
\text { yalty }\end{array}$ & 125 & 4.18 & .730 & $\begin{array}{c}-.28 \\
6 \\
\end{array}$ & .217 & -1.075 & .430 \\
\hline $\begin{array}{l}\text { BrandEquityHelps\&amp; } \\
\text { pefromensfruitfulbusiness }\end{array}$ & 125 & 4.05 & .728 & $\begin{array}{c}-.07 \\
4 \\
\end{array}$ & .217 & -1.092 & .430 \\
\hline Valid N (listwise) & 125 & & & & & & \\
\hline
\end{tabular}

The developed table (Table 3 ) is based on the statements asked in the questionnaire. From Table 3, it can be observed that the mean values of statements were ranging from 4.09 and 4.22. This means that the responses were in between agreement and strong agreement. The determined deviations from the collected data was under the range of 1 ; meaning that there was a consensus between the values. The negative values of skewness were mentioning the fact that the bell curve of the data can be shorter. The values of Kurtosis (Table 3) are also negative that support the results generated by skewness. 
British Journal of Marketing Studies

Vol. 8, Issue 4, Pp.49-66, July, 2020

Published by ECRTD- UK

Print ISSN: 2053-4043(Print), Online ISSN: 2053-4051(Online)

\section{Correlation analysis}

The correlation analysis is an important statistical analysis that can help the researcher in developing the relationship between the research variables. Therefore, the current study also follows the correlation analysis for its quantifiable data. This correlation will help the researcher in identifying the relation between the research variables.

Table 4: Correlation analysis

\begin{tabular}{|c|c|c|c|c|c|c|}
\hline \multicolumn{7}{|c|}{ Correlations } \\
\hline & & $\begin{array}{c}\text { StoreIm } \\
\text { age }\end{array}$ & $\begin{array}{c}\text { Brandele } \\
\text { ment }\end{array}$ & $\begin{array}{c}\text { Influenc } \\
\text { ers }\end{array}$ & $\begin{array}{l}\text { WebAdverti } \\
\text { sing }\end{array}$ & $\begin{array}{c}\text { Brandeq } \\
\text { uity }\end{array}$ \\
\hline \multirow[t]{3}{*}{$\begin{array}{l}\text { StoreImag } \\
\mathrm{e}\end{array}$} & $\begin{array}{l}\text { Pearson } \\
\text { Correlatio } \\
n\end{array}$ & 1 & $.592^{* *}$ & $.675^{* *}$ & $.410^{* *}$ & $.556^{* *}$ \\
\hline & $\begin{array}{ll}\begin{array}{l}\text { Sig. } \\
\text { tailed })\end{array} & (2- \\
\end{array}$ & & .000 & .000 & .000 & .000 \\
\hline & $\mathrm{N}$ & 125 & 125 & 125 & 125 & 125 \\
\hline \multirow[t]{3}{*}{$\begin{array}{l}\text { Brandelem } \\
\text { ent }\end{array}$} & $\begin{array}{l}\text { Pearson } \\
\text { Correlatio } \\
n\end{array}$ & $.592^{* *}$ & 1 & $.639^{* *}$ & $.413^{* *}$ & $.659^{* *}$ \\
\hline & $\begin{array}{ll}\text { Sig. } & (2- \\
\text { tailed })\end{array}$ & .000 & & .000 & .000 & .000 \\
\hline & $\mathrm{N}$ & 125 & 125 & 125 & 125 & 125 \\
\hline \multirow[t]{3}{*}{$\begin{array}{l}\text { Influencer } \\
\mathrm{s}\end{array}$} & $\begin{array}{l}\text { Pearson } \\
\text { Correlatio } \\
\mathrm{n}\end{array}$ & $.675^{* *}$ & $.639^{* *}$ & 1 & $.470^{* *}$ & $.518^{* *}$ \\
\hline & $\begin{array}{ll}\text { Sig. } & (2- \\
\text { tailed })\end{array}$ & .000 & .000 & & .000 & .000 \\
\hline & $\mathrm{N}$ & 125 & 125 & 125 & 125 & 125 \\
\hline \multirow[t]{3}{*}{$\begin{array}{l}\text { WebAdver } \\
\text { tising }\end{array}$} & $\begin{array}{l}\text { Pearson } \\
\text { Correlatio } \\
\mathrm{n}\end{array}$ & $.410^{* *}$ & $.413^{* *}$ & $.470^{* *}$ & 1 & $.553^{* *}$ \\
\hline & $\begin{array}{l}\text { Sig. } \\
\text { tailed })\end{array}$ & .000 & .000 & .000 & & .000 \\
\hline & $\mathrm{N}$ & 125 & 125 & 125 & 125 & 125 \\
\hline \multirow[t]{3}{*}{$\begin{array}{l}\text { Brandequi } \\
\text { ty }\end{array}$} & $\begin{array}{l}\text { Pearson } \\
\text { Correlatio } \\
\mathrm{n}\end{array}$ & $.556^{* *}$ & $.659^{* *}$ & $.518^{* *}$ & $.553^{* *}$ & 1 \\
\hline & $\begin{array}{l}\text { Sig. } \\
\text { tailed })\end{array}$ & .000 & .000 & .000 & .000 & \\
\hline & $\mathrm{N}$ & 125 & 125 & 125 & 125 & 125 \\
\hline
\end{tabular}

From the above-developed Table-4, the level of relationship between the variables can be identified. The Pearson correlation value between store image and brand equity is positive 0.556 ; meaning that there was a positive and moderate correlation between the variables. The 
British Journal of Marketing Studies

Vol. 8, Issue 4, Pp.49-66, July, 2020

Published by ECRTD- UK

Print ISSN: 2053-4043(Print), Online ISSN: 2053-4051(Online)

Pearson value of brand equity and brand element was also positive 0.659 ; depicting a positive and moderate relation between the variables. The Pearson value between influence and brand equity was positive 0.518 ; depicting a positive and moderate relation between variables. In last, the value of the Pearson coefficient between the brand equity and web advertising was positive 0.553 that depicting a strong moderate relationship between the variables.

\section{Regression analysis}

Another important statistical technique used in the research is based on regression analysis. The developed regression analysis helps the researcher in understanding the best model fit for the research variables; and can easily identify the strength and movement of the relationship between them. The whole regression analysis for the research is based on the three important tables of model summary, ANOVA table, and coefficients table.

Table 5: Model Summary.

\begin{tabular}{|c|c|c|c|c|c|}
\hline \multicolumn{6}{|c|}{ Model Summary ${ }^{b}$} \\
\hline Model & $\mathbf{R}$ & R Square & $\begin{array}{l}\text { Adjusted R } \\
\text { Square }\end{array}$ & $\begin{array}{l}\text { Std. } \begin{array}{r}\text { Error } \\
\text { of } \\
\text { Estimate }\end{array} \\
\text { the }\end{array}$ & $\begin{array}{l}\text { Durbin- } \\
\text { Watson }\end{array}$ \\
\hline 1 & $.742^{\mathrm{a}}$ & .550 & .535 & .490 & 1.761 \\
\hline
\end{tabular}

From developed Table 5 of the model summary, it can be determined that the value of $\mathrm{R}$ is 0.742 ; meaning that the developed regression model is $74.2 \%$ fit for regression analysis. Moreover, the value of R-square is 0.550 (Table 5). This explains the fact that the predictors of the research can enhance the dependent variable by 55\%. The Durbin Watson value of 1.761 also supports the findings of the model summary. The findings of the model summary are also supported by the 'Sig' values explained in the ANOVA table (Table 5).

Table 6: ANOVA table

\begin{tabular}{|c|c|c|c|c|c|c|}
\hline \multicolumn{7}{|c|}{$A N O V A^{a}$} \\
\hline \multicolumn{2}{|c|}{ Model } & Sum of & Df & Mean & $\mathbf{F}$ & Sig. \\
\hline \multirow[t]{3}{*}{1} & Regression & 35.224 & 4 & 8.806 & 36.722 & $.000^{\mathrm{b}}$ \\
\hline & Residual & 28.776 & 120 & .240 & & \\
\hline & Total & 64.000 & 124 & & & \\
\hline \multicolumn{7}{|c|}{ a. Dependent Variable: Brandequity } \\
\hline \multicolumn{7}{|c|}{$\begin{array}{l}\text { b. Predictors: (Constant), WebAdvertising, StoreImage, Brandelement, } \\
\text { Influencers }\end{array}$} \\
\hline
\end{tabular}

The ANOVA table (Table 6) explains that the 'Sig' value of the conducted regression analysis is '0.000'. This sig value in the ANOVA table (Table 6) defines the fact that the model summary (Table 6) contains such predictors and dependent variables that has an accurate level of association among them. The developed Coefficient table also supports the developed sig values in the ANOVA table (Table 6).

Table 7: Coefficients table. 
British Journal of Marketing Studies

Vol. 8, Issue 4, Pp.49-66, July, 2020

Published by ECRTD- UK

Print ISSN: 2053-4043(Print), Online ISSN: 2053-4051(Online)

\begin{tabular}{|c|c|c|c|c|c|c|}
\hline \multicolumn{7}{|c|}{ Coefficients $^{a}$} \\
\hline \multirow{2}{*}{\multicolumn{2}{|c|}{ Model }} & \multicolumn{2}{|c|}{$\begin{array}{l}\text { Unstandardized } \\
\text { Coefficients }\end{array}$} & \multirow{2}{*}{$\begin{array}{c}\text { Standardized } \\
\text { Coefficients } \\
\text { Beta } \\
\end{array}$} & \multirow[t]{2}{*}{$\mathbf{T}$} & \multirow[t]{2}{*}{ Sig. } \\
\hline & & B & Std. Error & & & \\
\hline \multirow[t]{5}{*}{1} & (Constant) & -.051 & .363 & & -.141 & .888 \\
\hline & StoreImage & .258 & .115 & .196 & 2.256 & .026 \\
\hline & Brandelement & .467 & .088 & .443 & 5.289 & .000 \\
\hline & Influencers & -.048 & .103 & -.043 & -.466 & .642 \\
\hline & WebAdvertising & .323 & .074 & .310 & 4.392 & .000 \\
\hline
\end{tabular}

From developed Table 7, it is observed that only two of the independent research variables have the sig values of 0.000 (lesser than the threshold of 0.05 ). This means that the brand element and web advertising practices have a significant and positive relation with the research dependent variable of brand equity. The B value for a Brand element is 0.467 depicting that brand element can directly affect brand equity by $46.7 \%$. Whereas the B value of Web advertising is 0.323 depicting a $32.3 \%$ affection on the brand equity of the domestic new luxury apparel. These facts are mainly supported by the values of the standardised coefficients of table 7. The fact was supported by the value of the standardised coefficient value of internal and external factors of framework, 0.443 and 0.310 respectively. These determined values of the standardised coefficients also explain the fact that the relation among the research variables in moving towards a positive direction.

\section{DISCUSSION}

It is very evident from this study that the brand elements, store image, influencers and web advertising play a significant role in the success of the businesses selling domestic new luxury apparel brand in the country's domestic markets. It was further explained by Tynan, McKechnie and Chhuon, (2010) that different branding strategies has been implemented by luxury brands in Pakistan. All of these brands are making their efforts to attract the customers towards the businesses for the purchase of domestic new luxury apparel brand. Though it can be observed from the prevailing market conditions that the competition level among the domestic luxury brands has been increased with the development of fashion trends among the young people of the country.

Further, it was also observed by Salman and Warraich (2016) that the young people are more inclined towards the purchases of the new luxury brands as the luxury brand management is making their efforts towards attracting the customers with different branding strategies based on the cultural values of the country and providing affordable and fashionable luxury.

Store Image has affected the young consumers' brand perception in Pakistan tremendously. Therefore, domestic new luxury apparel brands should focus on store image. Several studies have identified that there is a positive relationship between store image and store loyalty (Lassk, 2000; Mazursky and Jacoby, 1986; Osman, 1993). Managers should focus on store image as "it is the way the store is defined in the shopper's mind" (Martineau, 1958). Luxury 
shoppers' expectations have increased over time, they look for an enjoyable experience while shopping which makes them loyal with the brand. Western countries have successfully implemented this strategy and have seen tremendous results in attracting consumers. So, managers should implement this strategy as young consumers love innovative stores.

Brand Elements act as the identity of the brand, it has been found that young consumers are more interested to see a unique name, attractive logo, impressive packaging, creative slogans etc. Young consumers associate themselves with brand elements to show the status of their wealth and prestige and also to show their personality while socialising. These elements help them to acquire luxury brands as young consumers are brand conscious, they are attracted to elements if they are different and more appealing than those from competitors. Studies have found that brand elements are a great tool to enhance brand awareness and to facilitate the formation of strong brand associations (Keller, Aperia \& Georgson, 2008, Keller, 2003, Aaker 1991; Kohli and Labahn, 1997; Klink, 2001). So, it is important for managers to give keen focus to brand elements, as in the luxury apparel industry, their role is extraordinary.

Influencer marketing has become very famous in the luxury apparel industry of Pakistan because of digitisation. Influencers are the bloggers who have a large number of followers in society. They use platforms like Instagram and Facebook to attract people. It has been analysed that the young consumers of Pakistan are more attracted to influencers rather than celebrities. Young consumers nowadays are well aware of the fact that whatever celebrities endorse is not always true as they use professional photography, bright lights and scripted views. However, bloggers share their personal experiences based on real facts. Several studies by Jin and Phua, (2014); Utz, (2010); Graham, (2014); Yoganarasimhan, (2012); Cha et al. (2010); Hwang (2015); Feng (2016) Siegler, (2009); Wong (2014) stated that influencers play a significant role in increasing brand awareness, building brand associations and loyalty. Western countries have seen fruitful results after recruiting influencers for their brands as they bring traffic to the brands' websites. So, managers should adopt this strategy to attract young consumers.

Web advertising has showed incredible results in the Pakistani apparel industry. The internet has transformed the daily life of each individual as it has become a basic need of life. Young consumers are fashionable and up to date trend followers; they consider TV and Print advertisements as old fashioned and outdated. Web advertising is the tool which attracts them as it has provided an advanced medium of communication. Young consumers use YouTube, Facebook, and Instagram etc. to see advertisements rather than watching them on television. Smartphones has also played a great role in weakening the traditional advertising media such as TV and Print. Youth have smartphones which gives them easy access to the internet anytime, anywhere. Various studies have found that web advertising is the most effective and fast way to increase brand awareness (Ryan 1996; Korgaonkar and Wolin 2002; Danaher and Mullarkey 2003; Kotler 2004; McElfresh et al., 2007; Baltas 2003). So, managers should invest more on web advertising as there is less scope for TV and print advertising in Pakistan. Young consumers are less interested to watch TV or Magazines or Newspaper, instead they love to surf the web, play games online, doing shopping and watching ads. Thus, marketers or managers can successfully attract consumers and increase the high level of brand awareness 
British Journal of Marketing Studies

Vol. 8, Issue 4, Pp.49-66, July, 2020

Published by ECRTD- UK

Print ISSN: 2053-4043(Print), Online ISSN: 2053-4051(Online)

\section{CONCLUSION, LIMITATION AND FUTURE RESEARCH}

\section{CONCLUSION}

The current study develops the framework for the Pakistani domestic new luxury apparel businesses. The current study was aimed at examining the influence of the brand strategies on brand equity and on the buying pattern of the young consumers of Pakistan. This study also describes two concepts of luxury being new and old. The new luxury was described as affordable and fashionable; whereas, the old luxury was explained as a piece of art and dearer to the young consumers of Pakistan. It was also found that the concept of new luxury is well known among the young consumers of Pakistan. Young consumers are more conscious about the latest trends of the society and have more desire to buy domestic new luxury apparel as it is affordable and fashionable as compared to traditional luxury. Moreover, the study revealed four branding strategies; Store Image, Brand Elements, Influencers and Web Advertising building strong brand equity and influencing young consumers to buy a domestic new luxury apparel brand in Pakistan.

\section{Limitations and Future Research}

This study has only examined four branding strategies and its influence on brand equity, however future studies can add more strategies to examine the relationship with brand equity. Furthermore, this study has utilised non-probability sampling in collecting data from only one city of Pakistan: Karachi. Though, future studies can take multiple cities as each city has its own culture and trends. This study has been conducted based on new luxury apparel industry, however future studies can be conducted in different industry. Lastly, targeted population for this study is only young population of pakistan but future studies can be conducted will different population sample.

\section{REFERENCE}

Aaker, D. A., 1991. Managing brand equity : capitalizing on the value of a brand name/ David A. Aaker [Bibliographies Non-fiction]. New York ; London : Free Press, c1991.

Aaker, D.A. and Biel, A.L., 2013. Brand equity \& advertising: advertising's role in building strong brands. Psychology Press.

Aaker, D.A., 1992. The value of brand equity. Journal of business strategy, 13(4), pp.27-32.

Aiello, G.; DONVITO, R.; GODEY, B.; PEDERZOLI, D.; WIEDMANN, K.P.; HENNIGS, N.; SIEBELS, A.; CHAN, P. Placing Luxury Marketing on the research Agenda not only for the Sake of Luxury - An introduction: In: K.-P. WIEDMANN, \& H. N., Luxury Marketing: A challenge for theory and practice. Wiesbaden: Springer Gabler, 2009.

Ali, M., Amir, M. and Akram, M.W., 2016. The factors affecting attitudes and purchase intent for luxury fashion goods: an empirical study of Pakistani market. Oman Chapter of Arabian Journal of Business and Management Review, 34(2616), pp.1-19.

Alnsour, M.S. and Subbah, M.L., 2018. Impact of brand elements on brand equity: An applied study on Jordanian Corporations. African Journal of Marketing Management, 10(3), pp.17-27. 
British Journal of Marketing Studies

Vol. 8, Issue 4, Pp.49-66, July, 2020

Published by $\boldsymbol{E C R T D}-\boldsymbol{U K}$

Print ISSN: 2053-4043(Print), Online ISSN: 2053-4051(Online)

Bain and Company Report (2016) https://seekingalpha.com/article/4082331-examininggrowth-luxury-industry-asia-the-cult-luxury-brand (Accessed on 25-06-2018).

Baltas, G. (2003) "Determinants of internet advertising effectiveness: an empirical study" International Journal of market research, vol.45, p.505.

Bashir, S., Zeeshan, M.U.H.A.M.M.A.D., Sabbar, S.A.B.B.A.R.D.A.H.H.A.M., Hussain, R.I. and Sarki, I.H., 2013. Impact of cultural values and life style on impulse buying behavior: a case study of Pakistan. International Review of Management and Business Research, 2(1), p.193.

Bruce, M. and Kratz, C. (2007) "Competitive marketing of strategies of luxury fashion companies”. In T. Hines and M. Bruce (eds.) Fashion Marketing: Contemporary Issues. Second edition. Oxford: Elsevier Butterworth Heinemann, pp 130-150.

Bruhn, M., Schoenmueller, V. and Schäfer, D.B., 2012. Are social media replacing traditional media in terms of brand equity creation?. Management Research Review, 35(9), pp.770790 .

Cha, M., Haddadi, H., Benevenuto, F., Gummadi, K. (2010). Measuring user influence in Twitter: The million follower fallacy. Proceedings of the Fourth International AAAI Conference on Weblogs and Social Media, Washington D.C., USA.

Danaher, P. J. \& Mullarkey, G. W. (2003). Factors affecting online advertising recall: a study of students (pp 252 - 267). Journal of Advertising Research, 43, 252-267.

Dictionary, Cambridge (2014). Luxury Meaning in the Cambridge English Dictionary. [Online] Dictionary.cambridge.org. Available at: http://dictionary.cambridge.org/dictionary/english/luxury [Accessed 21 Feb. 2018].

Dictionary, Oxford (2014). Luxury Meaning in the Oxford English Dictionary. [Online] Dictionary.cambridge.org. Available at: http://dictionary. https://www.oed.com/dictionary/english/luxury [Accessed 21 Feb. 2018].

Emari, H., Jafari, A. and Mogaddam, M., 2012. The mediatory impact of brand loyalty and brand image on brand equity. African Journal of Business Management, 6(17), pp.5692-5701.

Emond, P. L. (2009). Managing fashion and luxury companies. Journal of Fashion Marketing and Management , 13(4), 582-584.

Farhana, M., 2012. Brand elements lead to brand equity: Differentiate or die. Information management and business review, 4(4), pp.223-233.

Feng, Y. (2016). Are you connected? Evaluating information cascades in online discussion about the \#RaceTogether campaign. Computers in Human Behavior, 54@, 43-53.

Fionda, A.M. and Moore, C.M., 2009. The Anatomy of the Luxury Fashion Brand. Journal of Brand Management, 16(5-6), pp.347-363.

Ghodeswar, B.M., 2008. Building brand identity in competitive markets: a conceptual model; Journal of product \& brand management, 17(1), pp.4-12 
British Journal of Marketing Studies

Vol. 8, Issue 4, Pp.49-66, July, 2020

Published by $\boldsymbol{E C R T D}-\boldsymbol{U K}$

Print ISSN: 2053-4043(Print), Online ISSN: 2053-4051(Online)

Godey, B., Pederzoli, D., Aiello, G., Donvito, R., Chan, P., Oh, H., Singh, R., Skorobogatykh, II, Tsuchiya, J. and Weitz, B., 2012. Brand and country-of-origin effect on consumers' decision to purchase luxury products. Journal of Business Research, 65 (10), 14611470 .

Graham, G. S. (2014). More Than Friends: Popularity on Facebook and its Role in Impression Formation. Journal of Computer-Mediated Communication, 19(3), 358-372.

Hanaysha, J., Abdullah, H.H. and Abd Ghani, N.H., 2013. Assessing the literature on brand equity: from past, present to future. Australian Journal of Basic and Applied Sciences, 7(14), pp.488-499.

Heine, Klaus (2012) The Concept of Luxury Brands, Edition: 2 ISSN: 2193-1208.

Hoeffler, S. and Keller, K.L., 2002. Building brand equity through corporate societal marketing. Journal of Public Policy \& Marketing, 21(1), pp.78-89.

Hwang, Y. (2015). Does opinion leadership increase the followers on Twitter. International Journal of Social Science and Humanity, 5(3), 258-264.

Iris Communications. (2017) The Fashion And Apparel Industry Of Pakistan [Online] Available from http://iriscommunications.com.pk/blog/fashion-and-apparel-industryof-pakistan/

Jin, S. A., Phua J. (2014). Following Celebrities' Tweets About Brands: The Impact of TwitterBased Electronic Word-of-Mouth on Consumers' Source Credibility Perception, Buying Intention, and Social Identification With Celebrities., Journal of Advertising, 43(2), 181-195.

Jung, J. and Shen, D., 2011. Brand equity of luxury fashion brands among Chinese and US young female consumers. Journal of East-West Business, 17(1), pp.48-69.

Kapferer, J. N., 1997. Managing luxury brands. Journal of Brand Management, 4 (4), 251-260.

Kapferer, Jean-Noel and Bastien, V., 2009. The Specificity of Luxury Management: Turning Marketing Upside Down. Journal of Brand Management, 16(5/6), pp.311-322.

Keller, K. L. (2002). Strategic Brand Management: Building, Measuring, and Management Brand Equity (Second Edition). Pearson Education Ltd.

Keller, K.L. 2008. Strategic brand management: Building, measuring, and managing brand equity. 3rd ed. Upper Saddle River, NJ: Prentice Hall.

Keller, K.L., 2010. Brand equity management in a multichannel, multimedia retail environment. Journal of Interactive Marketing, 24(2), pp.58-70.

Keller, K.L. (1993), "Conceptualizing, measuring and managing customerbased brand equity", Journal of Marketing, Vol. 57 No. 1, pp. 1-22.

Kevin Lane Keller; Tony Aperia; Mats Georgson (2008) Strategic Brand Management: A European Perspective Published by Financial Times Prentice Hall (2008). 
British Journal of Marketing Studies

Vol. 8, Issue 4, Pp.49-66, July, 2020

Published by ECRTD- $\boldsymbol{U K}$

Print ISSN: 2053-4043(Print), Online ISSN: 2053-4051(Online)

Kim, A.J. and Ko, E., 2012. Do social media marketing activities enhance customer equity? An empirical study of luxury fashion brand. Journal of Business Research, 65(10), pp.1480-1486.

Klink, R. R. (2001), 'Creating Meaninful New Brand Names: A Study of Semantics and Sound Symbolism', Journal of Marketing Theory and Practice, Vol. 9, No. 2, pp. 27-34.

Ko, E \& Megehee, CM 2012, Fashion marketing of luxury brands: Recent research issues and contributions', Journal of Business Research, vol. 65, no. 10, pp. 1395-1398.

Kohli, C. \& Labahn, D. W. (1997). Creating effective brand names: A study of the naming process. Journal of Advertising Research, 37(1), 67-75.

Korgaonkar, P. \& Wolin, L. D. (2002). Web usage, advertising, and shopping: relationship patterns. Internet Research: Electronic Networking Applications and Policy, 12(2), 191-204.

Kotler, P. and Keller, K.L. (2012) Marketing Management. 14th Edition, Pearson Education

Kotler, P., (2004), Marketing management, 11th International edition- Prentice-Hall, pp 706.

Kundi, A. (2018). Pakistan currently has largest percentage of young people in its history: report. [online] DAWN.COM. Available at: https://www.dawn.com/news/1405197 [Accessed 6 Aug. 2018].

Lassk, F.G (2000), "Investigating Aspects of Customer Satisfaction at the c-store: The c-store Product Mix and Image," Journal of Professional Services Marketing, vol. 21(2), pp. $15-26$.

Lehmann, D. R., Keller, K. L., \& Farley, J. U. (2008). The structure of survey-based brand metrics. Journal of International Marketing,16(4), 29-56.

Leone, R.P., Rao, V.R., Keller, K.L., Luo, A.M., McAlister, L. and Srivastava, R., 2006. Linking brand equity to customer equity. Journal of service research, 9(2), pp.125-138.

Lindquist, J.D (1974), "Meaning of Image: A Survey of Empirical and Hypothetical Evidence”, Journal of Retailing, vol. 50(4), pp. 29-38.

Martineau, P (1958), “The Personality of the Retail Store”, Harvard Business Review, vol. 36(1), pp. 47- 55.

Mazursky, D. and Jacoby, J. (1986) Exploring the Development of Store Images, Journal of Retailing, 62(2), pp.145-165.

McElfresh C, Mineiro P, Rodford M. (2007) Method for optimum placement of advertisements on a webpage, Patent Application Publication 2007-2008; 24:1-7.

Morrison, K. (2015). Report: 75\% of Marketers Are Using Influencer Marketing. Available Online: http://www.adweek.com/socialtimes/report-75-of-marketers-are-usinginfluencer-marketing/62821 [Accessed 26. November 2018].

Msci Index (2019) Emerging markets https://www.msci.com/www/fact-sheet/msci-emergingmarkets-index/07149641 (Accessed on 20-05-2019). 
British Journal of Marketing Studies

Vol. 8, Issue 4, Pp.49-66, July, 2020

Published by $\boldsymbol{E C R T D}-\boldsymbol{U K}$

Print ISSN: 2053-4043(Print), Online ISSN: 2053-4051(Online)

Mutsikiwa, M., Dhliwayo, K. and Basera, C.H., (2013) The impact of advertising on building brand equity: A case of Zimbabwean universities. European Journal of Business and Management, 5(9), pp.197-210.

Nam, J., Ekinci, Y. and Whyatt, G., 2011. Brand equity, brand loyalty and consumer satisfaction. Annals of Tourism Research, 38(3), pp.1009-1030.

Nath Sanyal, S. and Datta, S.K., 2011. The effect of perceived quality on brand equity: an empirical study on generic drugs. Asia Pacific Journal of Marketing and Logistics, 23(5), pp.604-625.

Okonkwo, U., 2009. The luxury brand strategy challenge. Journal of brand management, 16(56), pp.287-289.

Osman, M. (1993) A Conceptual Model of Retail Image Influence on Loyalty Patronage Behaviour, International Review of Retail, Distribution and Consumer Research, 3(2), pp. 33-48.

Pakistan and Gulf Economist, B. (2018). Bright prospect for fashion and apparel industry in South Asia - Pakistan \& Gulf Economist. [online] Pakistan \& Gulf Economist. Available at: http://www.pakistaneconomist.com/2017/02/06/bright-prospect-fashionapparel-industry-south-asia/ [Accessed 6 Aug. 2018].

Ryans, C. (1996) Consumer Resources. Journal of Small Business Management, 34 (1996): 63-65.

Salman F., Warraich U.A (2016) An Empirical Study to Examine Consumer Behavior towards Luxury Brands in Pakistan; Global Management Journal for Academic \& Corporate Studies 6 (1), 79.

Samaa. (2017) Pakistan's fastest retail economy to grow 50pc in five years to 2021 [Online] Available from <https://www.samaa.tv/economy/2017/09/pakistans-retail-marketshows-surprising-growth/> [14 Nov. 17].

Sasmita, J. and Mohd Suki, N., 2015. Young consumers' insights on brand equity: Effects of brand association, brand loyalty, brand awareness, and brand image. International Journal of Retail \& Distribution Management, 43(3), pp.276-292.

Schlosser, A. E., Shavitt, S., \& Kanfer, A. (1999). Survey of Internet users' attitudes toward Internet advertising. Journal of Interactive Marketing, 13(3), 34-54.

Selvakumar, J.J. and Vikkraman, P., (2011) Impact of advertising and price promotions on brand equity in service sector. Journal of contemporary research in management, 6(3), p.51.

Shukla, P. and Purani, K. (2012), Comparing the importance of luxury value perceptions in cross-national contexts, Journal of Business Research, 65 (10), 1417-

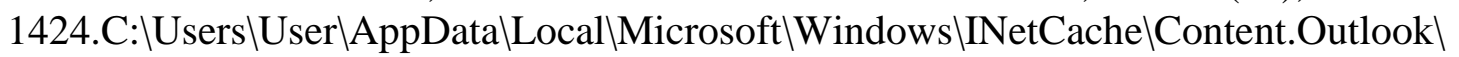
R0YEA3XXIMsci Index (2019) Emerging markets https:Iwww.msci.comlwwwlfactsheetlmsci-emerging-markets-index 107149641 (Accessed on 20-05-2019) 
British Journal of Marketing Studies

Vol. 8, Issue 4, Pp.49-66, July, 2020

Published by $\boldsymbol{E C R T D}-\boldsymbol{U K}$

Print ISSN: 2053-4043(Print), Online ISSN: 2053-4051(Online)

Siegler, M.G. (2009). Twitter's golden ratio (That no one likes to talk about). Retrieved February 26, 2018 from http://techcrunch.com/2009/08/26/twitters-golden-ratio-thatnoone-likes-to-talk-about.

Silverstein, M., Butman, J. and Fiske, N. (2005) Trading up: Why Consumers Want New Luxury Goods, and How Companies Create Them.

Tong, X. and Hawley, J., 2009. Creating brand equity in the Chinese clothing market: The effect of selected marketing activities on brand equity dimensions. Journal of Fashion Marketing and Management; 13. 566-581. 10.1108/13612020910991411.

Truong, Y., McColl, R., \& Kitchen, P. J. (2009). New luxury brand positioning and the emergence of masstige brands. Journal of Brand Management, 16 (5), 375-382.

Truong, Y., Simmons, G., McColl, R. and Kitchen, P. J. (2008) New luxury brands: Between status and conspicuousness, Journal of Strategic Marketing, Summer/Fall edn, 16 (3): 189-203.

Tsimonis, G. and Dimitriadis, S., (2014) Brand strategies in social media. Marketing Intelligence \& Planning, 32(3), pp.328-344.

Tynan, C., McKechnie, S. and Chhuon, C. (2010). Co-creating value for luxury brands. Journal of Business Research, 63(11), pp.1156-1163.

Utz, S. (2010). Show me your friends and I will tell you what type of person you are: How one's profile, number of friends, and type of friends influence impression formation on social network sites. Journal of Computer-Mediated Communication, 15(2), 314-335.

Vigneron, F. and Johnson, L. W., 2004. Measuring perceptions of brand luxury. Journal of Brand Management, 11 (6), 484-506.

Wong, K. (2014). The explosive growth of influencer marketing and what it means for you. $\begin{array}{llll}\text { Retrieved } \quad \text { February } & 2618 \text { from }\end{array}$ http://www.forbes.com/sites/kylewong/2014/09/10/theexplosive-growth-ofinfluencer-marketing-and-what-it-means-for-you/\#660f82d4595f.

World Population Review (2018). Karachi Population 2018. [Online] Worldpopulationreview.com. Available at: http://worldpopulationreview.com/worldcities/karachi-population/ [Accessed 17 Aug. 2018].

Yoganarasimhan, H. (2012). Impact of Social Network Structure on Content Propagation - A Study using YouTube Data. Quantitative Marketing and Economics, 10(1), 111-150.

Yoo, B., Donthu, N., and Lee, S. (2000). An examination of selected marketing mix elements and brand equity. Academy of Marketing Science, 28(2), 195-212.

Zimmer, M.R and Golden, L.L (1988), "Impressions of Retail Stores: A Context Analysis of Consumer Images”, Journal of Retailing, vol. 64(3), pp. 265-93. 